\title{
KELELAHAN DAN GAYA HIDUP PADA PASIEN HIPERTENSI
}

\author{
Ferdy Lainsamputty ${ }^{1}$ \\ 1. Dosen Program Studi S1 Keperawatan, Sekolah Tinggi Ilmu Kesehatan Husada Mandiri Poso, Jl. Pulau \\ Kalimantan No. 29, Poso, Sulawesi Tengah, 94612, Indonesia
}

E-mail: Lainsamputtyferdy@gmail.com

\begin{abstract}
Hypertension is a current significant health problem in many countries including Indonesia. Fatigue is a common symptom that often occurs in hypertensive patients that might be worsen by unhealthy lifestyles along with other symptoms of hypertension. The study aimed to explore the relationship between fatigue and lifestyle among patients with hypertension. This was a descriptive correlational study with cross-sectional approach using 68 convenience samples in a general hospital of Central Sulawesi Province, Indonesia. The questionnaires were Multidimensional Assessment of Fatigue (MAF) and Health Promotion Lifestyle Profile II (HPLP II). Descriptive statistics and Spearman rank correlation were used to explore the relationships between variables and domains. Overall, lifestyle was correlated to fatigue $(r=0,28, p<0.05)$. Hypertensive patients with higher degree of fatigue, performed a better lifestyle. More effective strategies such as health education, professional consultation, support and group sharing need to be done to improve the lifestyle of patients.
\end{abstract}

Keywords: Fatigue, hypertension, lifestyle.

\begin{abstract}
Abstrak
Penyakit hipertensi merupakan masalah kesehatan signifikan yang sedang dialami di banyak negara termasuk Indonesia. Kelelahan adalah gejala umum yang terjadi pada pasien hipertensi yang mungkin diperburuk oleh gaya hidup tidak sehat, bersama dengan gejala hipertensi lainnya. Penelitian ini bertujuan untuk mengeksplorasi hubungan kelelahan dan gaya hidup pada pasien hipertensi. Penelitian ini berjenis deskriptif korelasi berpendekatan potong lintang dengan 68 sampel yang direkrut menggunakan teknik convenience sampling di salah satu rumah sakit umum daerah di Provinsi Sulawesi Tengah, Indonesia. Kuesioner yang digunakan yaitu MAF dan HPLP II. Statistik deskriptif dan Spearman Rank Correlation digunakan untuk mencari hubungan antar variabel dan domain-domainnya. Secara keseluruhan, gaya hidup berhubungan signifikan dengan kelelahan $(r=0,28, p<0,05)$. Penderita hipertensi yang menderita kelelahan berat, menerapkan gaya hidup yang lebih baik. Strategi yang lebih efektif dalam penyuluhan kesehatan, konsultasi profesional, support dan sharing group, perlu dilakukan untuk meningkatkan gaya hidup.
\end{abstract}

Kata Kunci: Gaya hidup, hipertensi, kelelahan.

\section{Pendahuluan}

Hipertensi berkontribusi signifikan dalam masalah kesehatan berbagai negara di dunia. Berdasarkan data dari World Health Organisation [WHO] (2013), dari 17 juta kematian karena penyakit kardiovaskuler, lebih dari separuhnya diakibatkan komplikasi hipertensi. Sekitar satu dasawarsa yang lalu, secara global 1,39 miliar penduduk dunia menderita hipertensi. Angka ini didominasi oleh negara-negara berkembang dibandingkan dengan negara berpenghasilan tinggi $(28,5 \%)$ (Mills et al., 2016).

American Heart Association [AHA] (2017) menyebutkan bahwa populasi dewasa ( $>20$ tahun) pengidap hipertensi berjumlah 74,5 juta jiwa. Namun, hanya $5-10 \%$ kasus yang penyebabnya dapat didentifikasi. Diprediksikan akan ada penambahan kasus sekitar $80 \%$ utamanya di negara- 
negara maju tahun 2025 (Suoth, Bidjuni, \& Malara, 2014).

Di Indonesia, hipertensi merupakan penyakit berprevalensi cukup tinggi $(34,11 \%)$. Tiga provinsi yang memiliki angka tertinggi yaitu Kalimantan Selatan $(44,13 \%)$, Jawa Barat $(39,6 \%)$, dan Kalimantan Timur (39,3\%) (Kementerian Kesehatan Republik Indonesia, 2019). Daerah-daerah Indonesia lainnya seperti di Sulawesi Tengah, juga terus bertambah. Contohnya data Kabupaten Poso yang dirilis oleh Dinas Kesehatan pada tahun 2017 tercatat ada 5.941 kasus. Di tahun 2018, naik menjadi 7.254 kasus (Dinas Kesehatan Kabupaten Poso, 2018).

Hipertensi dapat mengancam hidup penderitanya, tanpa memandang umur. Penyakit ini harus cepat ditindaklanjuti sebab dapat menimbulkan penyakit stroke, jantung, dan sebagainya, bahkan kematian. Meningkatnya hipertensi dipengaruhi oleh gaya hidup buruk seperti kurang atau tidak rutinnya berolahraga, aktif merokok, makan makanan kurang bernutrisi, dan gangguan psikologis, terutama stres (Rachmawati, 2013; Shimbo, 2016). Modifikasi gaya hidup yang tepat adalah langkah awal mencegah hipertensi (Hozawa, 2011; Kokubo et al., 2008).

Selain pusing dan sakit kepala, salah satu manifestasi klinis hipertensi yang umum adalah kelelahan (Wang et al., 2010). Hipertensi dapat membuat jantung membesar. Ketika jantung tidak kuat lagi mendorong darah menyebar keseluruh tubuh mengakibatkan sebagian darah akan menumpuk pada jaringan seperti di paru-paru dan tungkai, sehingga akan terjadi sesak nafas. Bila kebutuhan oksigen kurang tercukupi dapat menyebabkan sirkulasi darah terhambat. Akibatnya terjadi penumpukan sisa metabolisme pada daerah tungkai yang menyebabkan terjadinya fatigue atau kelelahan. Kelelahan dianggap sebagai salah satu masalah kesehatan dan cukup mengancam kualitas hidup individu bila keadaannya semakin parah. Gejala yaitu depresi, gangguan tidur, penyakit kardiovaskuler, dan gangguan fungsi lambung (Yogisutanti, Kusnanto, Setyawati, \& Otsuka, 2013).

Kelelahan biasanya dimulai dari munculnya rasa letih yang berlanjut pada kelelahan mental ataupun fisik sehingga mengganggu dalam aktivitas normal. Keadaan ini berbeda dengan rasa letih atau mengantuk biasa, dan sangat melemahkan serta paling sering dilaporkan oleh pasien penyakit kronis. Hal ini akan berlangsung secara berkesinambungan dan tidak mereda dengan istirahat (Putri, 2018).

Lansia yang berusia 45 tahun atau lebih mempunyai resiko terkena hipertensi dan beresiko mengalami kelelahan, terutama pada laki-laki karena berkurangnya kekuatan otot hampir 2 kali lipat (DeJean, Giacomini, Vanstone, \& Brundisini, 2013; Goodpaster et al., 2006). Kelelahan bahkan berefek besar pada status kesehatan dan dapat menyebabkan kematian (Moreh, Jacobs, \& Stessman, 2010). Penelitian Lin et al. (2015) pada populasi lansia lakilaki di China juga menemukan bahwa kelelahan berhubungan dengan faktor kesehatan dan gaya hidup termasuk di dalamnya asupan alkohol dan latihan fisik secara teratur.

WHO menyatakan bahwa gaya hidup sebagai hasil interaksi antara sifat pribadi, hubungan sosial, lingkungan, dan keadaan sosial ekonomi (da Silva, Colosimo, \& Pierin, 2010; Kaufman, Rajataramya, Tanomsingh, Ronis, \& Potempa, 2012). Gaya hidup setiap individu memainkan peran penting dalam perkembangan penyakit hipertensi. Penelitian telah menunjukkan bahwa nutrisi, aktivitas fisik, stres, merokok, kontrol berat badan, istirahat, dan tidur adalah faktor gaya hidup yang sangat penting (Karimiyar Jahromy, Yousefi Maghsoudbeiki, Shamsi, Sadeghi, \& Charkhandaz, 2013). Banyaknya penyakit saat ini terkait erat penerapan gaya hidup buruk. Guna mendapatkan keadaan fisik dan psikis yang sehat, dibutuhkan kontinutitas pelaksanaan gaya hidup yang sehat pula. Namun, jika terus mengabaikannya, dalam jangka panjang penderita hipertensi akan mendapatkan efek buruk berupa timbulnya penyakit kronik lain seperti penyakit pada jantung, otak, dan bahkan masalah psikis seperti depresi dan stres (Ridwan \& Nurwanti, 2016).

Hipertensi adalah penyakit yang perlu diseriusi. Informasi terkait kelelahan dan gaya hidup pada populasi ini juga masih terbatas. Penelitian ini memiliki tujuan untuk mengeksplorasi hubungan kelelahan dan gaya hidup pasien hipertensi. Memahami hubungan kedua variabel ini pada pasien hipertensi, cukup diperlukan untuk perencanaan perawatan yang lebih baik.

\section{Metode}

Penelitian ini berjenis deskriptif korelasi dan berpendekatan potong lintang. Sampel direkrut dari poli interna menggunakan teknik convenience sampling di sebuah rumah sakit umum daerah Provinsi Sulawesi Tengah, Indonesia, pada bulan Juni-Juli 2019. Kriteria inklusinya yaitu pasien yang terdiagnosa hipertensi oleh dokter, berusia 18 tahun ke atas (dewasa), dapat berkomunikasi dengan lancar menggunakan Bahasa Indonesia, dan bersedia terlibat sebagai responden. Pasien hipertensi dengan gangguan psikiatrik/mental dan menderita kanker merupakan kriteria eksklusi. Berdasarkan perhitungan menggunakan Rule of Thumbs (Green, 
1991), maka didapatkan 58 target sampel penelitian. Namun, mempertimbangkan resiko kehilangan data, dilakukanlah penambahan sampel sebanyak 10 orang (Dong \& Peng, 2013; Enders \& Bandalos, 2001). Secara keseluruhan, sampel yang direkrut sebanyak 68 pasien hipertensi.

Data demografi, karakteristik kesehatan, dan karakteristik penyakit dihimpun menggunakan kuesioner. Data demografi termasuk umur, jenis kelamin, pendidikan, dan pekerjaan. Karakteristik kesehatan yaitu indeks massa tubuh (IMT), merokok, dan olahraga. Sedangkan karakteristik penyakit yaitu faktor keturunan, klasifikasi, durasi penyakit, konsumsi garam, dan pengobatan hipertensi.

Kuesioner Multidimensional Assessment of Fatigue (MAF) digunakan untuk mengkaji kelelahan (Tack, 1991). Terdapat 16 pernyataan/pertanyaan tentang skala MAF, tetapi sesuai panduan hanya item nomor 1-15 yang dimasukkan untuk menghitung indeks fatigue global (Global Fatigue Index/GFI). Skor terendah dimulai dari 1 (tidak ada kelelahan) hingga 50 (kelelahan berat). Skor yang tinggi menunjukkan kelelahan yang lebih berat. Keenam belas pertanyaan ini dibagi menjadi 4 domain kelelahan: keparahan (dalam pertanyaan 1-2), tekanan (3), waktu (15-16) dan gangguan dalam aktivitas seharihari seperti pada pekerjaan rumah tangga, memasak, mandi, berpakaian, bekerja, bersosialisasi, seksual, rekreasi, belanja, berjalan, dan olahraga (4-14). Individu diminta untuk merefleksikan pola kelelahan selama seminggu sebelumnya. Untuk menghitung GFI, konversikan hasil jawaban pertanyaan nomor 15 ke skala $0-10$, dengan cara mengalikan hasilnya dengan angka 2,5. Hasil konversi nomor 15 tersebut kemudian dijumlahkan dengan hasil nomor 1, 2, dan 3 , beserta nilai rata-rata dari nomor 4-14. Skor pada setiap item tidak akan diberikan bila responden mengindikasikan bahwa mereka "tidak melakukan aktivitas apa-apa untuk alasan lain selain kelelahan". Jika responden memilih tidak ada kelelahan pada item nomor 1 , maka diberikan skor 0 pada item nomor 2-16. Kuesioner MAF telah digunakan pada beberapa populasi di Indonesia seperti pada pasien gagal ginjal kronik (Khusniyati, Yona, \& Kariasa, 2019) dan gagal jantung (Lainsamputty \& Chen, 2018), dengan hasil uji psikometrik yang dapat diterima. Cronbach's alpha kuesioner MAF dalam penelitian ini yaitu 0,75 .

Health Promoting Lifestyle Profile (HPLP II) adalah instrumen pengukur gaya hidup dalam penelitian ini (Walker \& Hill-Polerecky, 1996). Ada 52 pertanyaan dengan skor masing-masing 1-4 (1=tidak pernah, 2=kadang-kadang, 3=sering, 4=rutin) yang mencakup 6 subskala yaitu tanggung jawab kesehatan (dalam pertanyaan 3, 9, 15, 21, 27, 33, 39,
$45,51)$, aktivitas fisik $(4,10,16,22,28,34,40,46)$, nutrisi $(2,8,14,20,26,32,38,44,50)$, pertumbuhan spiritual $(6,12,18,24,30,36,42,48,52)$, hubungan interpersonal $(1,7,13,19,25,31,37,43,49)$, manajemen stres $(5,11,17,23,29,35,41,47)$. Skor gaya hidup keseluruhan diperoleh dengan menghitung rata-rata jawaban individu terhadap semua pertanyaan. Enam nilai subskala diperoleh dengan cara yang sama yaitu dengan menghitung nilai rata-rata. Skor terendah 1 dan skor tertinggi 4 . Semakin tinggi skor yang didapat, mengindikasikan semakin baik gaya hidup pasien. Uji validitas dan reliabilitas versi Bahasa Indonesia dari HPLP II ditemukan cukup baik dan telah digunakan pada beberapa populasi di Indonesia termasuk penderita hipertensi (Giena, Thongpat, \& Nitirat, 2018), perawat (Damayanti, Dino, \& Donnelly, 2020), dan ibu hamil (Iqomatulhaq \& Solehati, 2019). Cronbach's alpha kuesioner HPLP II dalam penelitian ini yaitu 0.93 .

Sebelum dilakukan pengambilan data, penelitian ini telah mendapatkan komite etik dengan izin No.: 928A/420/2019. Pasien yang memiliki kesesuaian dengan kriteria, diarahkan oleh dokter dan perawat saat kunjungan ke poli penyakit dalam. Tujuan dan prosedur penelitian kemudian dijelaskan secara rinci. Saat menyatakan bersedia untuk berpartisipasi, pasien dihubungi secara langsung oleh peneliti secara individual. Kerahasiaan data responden benar-benar dijaga. Lembaran Informed consent juga harus diisi oleh responden. Diberikan kesempatan pada responden untuk mengundurkan diri saat merasa tidak nyaman dalam penelitian. Pengumpulan data diperoleh melalui wawancara dan pengisian kuesioner. Semua kuesioner yang terisi, disimpan di tempat yang dirahasiakan dan hanya dapat diakses bagi yang memiliki izin.

Analisa data hasil penelitian menggunakan perangkat lunak komputer khusus statistik. Pendekatan analisis data dalam penelitian ini meliputi: 1) Statistik deskriptif (rata-rata, standar deviasi, frekuensi, persentase, range) untuk faktor demografi, karakteristik kesehatan, karakteristik penyakit, kelelahan, dan gaya hidup; 2) Spearman Rank Correlation digunakan untuk menginvestigasi hubungan antara kelelahan dan gaya hidup. Level signifikansi yang ditetapkan yaitu 0,05.

\section{Hasil \\ Deskripsi Data Demografik, Karakteristik Kesehatan, dan Penyakit Responden}

Data demografi dari 68 responden digambarkan pada Tabel 1. Usia rata-rata responden adalah 57,78 ( $\mathrm{SD}=10,42)$, dengan rentang 31-79 tahun. Mayoritas responden berjenis kelamin perempuan sejumlah 35 orang $(51,5 \%)$. Berdasarkan tingkat pendidikan, 
golongan responden terbanyak yaitu yang berpendidikan SD sejumlah 22 orang $(32,4 \%)$ dan yang paling sedikit responden yang mengecap pendidikan di perguruan tinggi berjumlah 11 orang $(16,1 \%)$. Pekerjaan yang paling banyak digeluti yaitu petani berjumlah 29 orang $(42,6 \%)$ dan yang paling sedikit yaitu guru berjumlah 3 orang $(4,4 \%)$. Para responden memiliki IMT rata-rata $23,37 \mathrm{~kg} / \mathrm{m}^{2}$ $(\mathrm{SD}=2,16)$, dengan kisaran $18-28 \mathrm{~kg} / \mathrm{m}^{2}$. Responden perokok sebanyak 27 orang $(39,7 \%)$. Terdapat 56 responden yang tidak rutin berolahraga $(82,4 \%)$. Responden yang orang tuanya pengidap hipertensi sebanyak 53 orang $(77,9 \%)$. Tiga puluh dua responden termasuk dalam hipertensi derajat 1 $(47,1 \%), 26$ responden derajat $2(38,2 \%)$, dan 10 responden menderita hipertensi krisis $(14,7 \%)$.

Lamanya pasien menderita hipertensi berkisar ratarata 2,31 tahun $(\mathrm{SD}=1,11)$ dengan rentang $1-5$ tahun. Lebih dari setengah responden patuh terkait konsumsi garam, yaitu sejumlah 36 orang $(52,9 \%)$. Rata-rata jumlah obat hipertensi yang digunakan adalah 1,29 (SD=0,46), berkisar sebanyak 1-2 jenis obat. Ada $70,59 \%$ responden mengonsumsi satu obat, sedangkan pengguna dua obat sekaligus sebanyak $29,41 \%$. CCB adalah golongan obat yang paling banyak digunakan oleh 56 orang $(82,4 \%)$.

Tabel 1 Data Demografi dan Karakteristik Kesehatan serta Penyakit Responden $(n=68)$

\begin{tabular}{|c|c|}
\hline Variabel & Rata-rata \pm SD / n (\%) \\
\hline Umur & $57,78 \pm 10,42$ \\
\hline \multicolumn{2}{|l|}{ Jenis Kelamin } \\
\hline Laki - Laki & $33(48,5)$ \\
\hline Perempuan & $35(51,5)$ \\
\hline \multicolumn{2}{|l|}{ Pendidikan } \\
\hline Tidak Sekolah & $1(1,5)$ \\
\hline SD & $22(32,4)$ \\
\hline SMP & $18(26,5)$ \\
\hline SMA & $16(23,5)$ \\
\hline Perguruan Tinggi & $11(16,1)$ \\
\hline \multicolumn{2}{|l|}{ Pekerjaan } \\
\hline Tidak Bekerja & $5(7,4)$ \\
\hline Petani & $29(42,6)$ \\
\hline PNS & $8(11,8)$ \\
\hline IRT & $20(29,4)$ \\
\hline Guru & $6(8.8)$ \\
\hline IMT & $23,37 \pm 2,16$ \\
\hline \multicolumn{2}{|l|}{ Merokok } \\
\hline Tidak & $41(60,3)$ \\
\hline $\mathrm{Ya}$ & $27(39,7)$ \\
\hline \multicolumn{2}{|l|}{ Olahraga } \\
\hline Tidak & $56(82,4)$ \\
\hline $\mathrm{Ya}$ & $12(17,6)$ \\
\hline \multicolumn{2}{|l|}{ Faktor Keturunan } \\
\hline Tidak & $15(22,1)$ \\
\hline $\mathrm{Ya}$ & $53(77,9)$ \\
\hline \multicolumn{2}{|l|}{ Klasifikasi } \\
\hline Derajat 1 & $32(47,1)$ \\
\hline Derajat 2 & $26(38,2)$ \\
\hline Derajat 3 & $10(14,7)$ \\
\hline
\end{tabular}

\begin{tabular}{lc}
\hline \multicolumn{1}{c}{ Variabel } & Rata-rata \pm SD / n $(\%)$ \\
\hline Durasi (tahun) & $2,31 \pm 1,11$ \\
KKG & $32(47,1)$ \\
Tidak & $36(52,9)$ \\
Ya & $1,29 \pm 0,46$ \\
Jumlah Pengobatan & $48(70,59)$ \\
Satu & $20(29,41)$ \\
Dua & $3(4,4)$ \\
Jenis Obat & $29(42,6)$ \\
ACEi & $56(82,4)$ \\
ARB & \\
CCB & \\
Catatan: SD=Sekolah Dasar; SMP=Sekolah Menengah Pertama; \\
SMA=Sekolah Menengah Atas; PNS=Pegawai Negeri Sipil; \\
IRT=Ibu Rumah Tanggah; IMT=Indeks Masa Tubuh; ; \\
KKG=Kepatuhan Konsumsi Garam; ACEI=Angiotensin- \\
Converting Enzyme-Inhibitor; ARB=Angiotensin Receptor \\
Blocker; CCB=Calcium Channel Blocker.
\end{tabular}

\section{Deskripsi Kelelahan Responden}

Skor rata-rata indeks kelelahan global (GFI/Global Fatigue Index) seperti yang terdapat pada tabel 2, berkisar 12,50-33,50 dengan rata-rata 18,16 $(\mathrm{SD}=3,31)$. Domain keparahan memiliki nilai ratarata 3,16 $(\mathrm{SD}=0,61)$, sedangkan tekanan rata-ratanya 2,31 $(\mathrm{SD}=1,05)$. Domain derajat terganggunya aktivitas memiliki rerata $3,32(\mathrm{SD}=0,76)$, sedangkan waktu rata-ratanya $2,37(\mathrm{SD}=0,45)$.

\section{Tabel 2 Domain Kelelahan dan GFI $(n=68)$}

\begin{tabular}{clcc}
\hline No. & \multicolumn{1}{c}{ Domain } & Rata-rata \pm SD & Range \\
\hline 1. & Keparahan & $3,16 \pm 0,61$ & $1,69-5,75$ \\
2. & Tekanan & $2,31 \pm 1,05$ & $1,00-7,00$ \\
3. & Derajat & & \\
& terganggunya & & \\
& aktivitas & $3,32 \pm 0,76$ & $1,27-6,27$ \\
4. & Waktu & $2,37 \pm 0,45$ & $1,00-3,00$ \\
& GFI & $18,16 \pm 3,31$ & $12,50-33,50$ \\
\hline \multicolumn{2}{l}{ Catatan: GFI=Global Fatigue Index. }
\end{tabular}

\section{Deskripsi Gaya Hidup Responden}

Tabel 3 mendeskripsikan total skor dan subskala gaya hidup. Secara keseluruhan nilai rata-rata gaya hidup yaitu 2,02 $(\mathrm{SD}=0,19)$. Subskala hubungan interpersonal memiliki skor tertinggi dari semua subskala gaya hidup dengan nilai rata-rata 2,17 ( $\mathrm{SD}=0,29)$, tanggung jawab kesehatan 2,15 ( $\mathrm{SD}=0,25)$, nutrisi $2,11 \quad(\mathrm{SD}=0,33)$, pertumbuhan spiritual 2,07 ( $\mathrm{SD}=0,36)$, manajemen stres 1,98 $(\mathrm{SD}=0,27)$, dan aktivitas fisik sebagai domain dengan nilai rata-rata terendah $1,54(\mathrm{SD}=0,37)$.

Tabel 3 Gaya Hidup dan Subskalanya $(n=68)$

\begin{tabular}{clcc}
\hline No. & \multicolumn{1}{c}{ Subskala } & $\begin{array}{c}\text { Rata-rata } \\
\mathbf{\pm} \text { SD }\end{array}$ & Range \\
\hline 1. & Tanggung jawab & & \\
& kesehatan & $2,15 \pm 0,25$ & $1,33-2,89$ \\
2. & Aktivitas fisik & $1,54 \pm 0,37$ & $1,00-2,75$ \\
\hline
\end{tabular}




\begin{tabular}{clcc}
\hline No. & \multicolumn{1}{c}{ Subskala } & $\begin{array}{c}\text { Rata-rata } \\
\mathbf{\pm} \text { SD }\end{array}$ & Range \\
\hline 3. & Nutrisi & $2,11 \pm 0,33$ & $1,33-2,89$ \\
4. & $\begin{array}{l}\text { Pertumbuhan } \\
\text { spiritual }\end{array}$ & $2,07 \pm 0,36$ & $1,11-3,00$ \\
5. & Hubungan & & \\
& interpersonal & $2,17 \pm 0,29$ & $1,56-2,89$ \\
6. & Manajemen stres & $1,98 \pm 0,27$ & $1,25-2,75$ \\
& Skor Gaya Hidup & $2,02 \pm 0,19$ & $1,60-2,60$ \\
\hline
\end{tabular}

\section{Kelelahan dan Gaya Hidup}

Domain keparahan kelelahan berhubungan sangat signifikan dengan subskala aktivitas fisik ( $\mathrm{r}=0,36$, $\mathrm{p}<0,01$ ), tetapi tidak berhubungan dengan 5 subskala gaya hidup lainnya. Domain tekanan kelelahan didapati berhubungan secara signifikan dengan subskala nutrisi $(\mathrm{r}=0,28, \mathrm{p}<0,05)$, hubungan interpersonal $(\mathrm{r}=0,25, \mathrm{p}<0,05)$, dan gaya hidup keseluruhan $(\mathrm{r}=0.35, \mathrm{p}<0,01)$. Domain derajat terganggunya aktivitas akibat kelelahan hanya ditemukan berhubungan sangat signifikan dengan subskala aktivitas fisik $(r=0,34, p<0,01)$. Sedangkan domain waktu kelelahan tidak ditemukan berhubungan dengan seluruh subskala gaya hidup. Kelelahan secara keseluruhan (GFI) memiliki hubungan yang sangat signifikan dengan subskala nutrisi $(\mathrm{r}=0,37, \mathrm{p}<0,01)$ dan skor gaya hidup secara keseluruhan $(\mathrm{r}=0,28, \mathrm{p}<0,05)$.

Tabel 4 Koefisien Korelasi Kelelahan dan Gaya Hidup $(\mathbf{n}=68)$

\begin{tabular}{llllll}
\hline Variabel & MAF & MAF & MAF & MAF & \multirow{2}{*}{ GFI } \\
\hline HPLP II-1 & 0,05 & 0,05 & 0,07 & $-0,11$ & $-0,01$ \\
HPLP II-2 & $0,36^{* *}$ & 0,17 & $0,34 * *$ & 0,02 & 0,15 \\
HPLP II-3 & 0,21 & $0,28^{*}$ & 0,14 & 0,17 & $0,37 * *$ \\
HPLP II-4 & 0,01 & 0,23 & $-0,00$ & 0,03 & 0,20 \\
HPLP II-5 & $-0,02$ & $0,25 *$ & $-0,06$ & $-0,03$ & 0,19 \\
HPLP II-6 & 0,01 & 0,17 & 0,04 & 0,03 & 0,04 \\
HPLP II & 0,18 & $0,35^{* *}$ & 0,16 & 0,03 & $0,28^{*}$ \\
\hline Catatan: & $* p<0.05 ;$ & $* * p<0.01$ & level & $(2$-tailed); HPLP II- \\
I=Tanggungjawab kesehatan; HPLP II-2=Aktivitas fisik; HPLP \\
II-3=Nutrisi; HPLP II-4=Pertumbuhan spiritual; HPLP II- \\
5=Hubungan interpersonal; HPLP II-6=Manajemen stres; HPLP \\
II= Health Promotion Lifestyle Profile II, MAF I=Keparahan; \\
MAF 2=Tekanan; MAF 3=Derajat terganggunya aktivitas; MAF \\
4=Waktu; GFI=Global Fatigue Index.
\end{tabular}

\section{Pembahasan}

Rata-rata umur pasien hipertensi dalam penelitian ini adalah 57,78 tahun, di mana umur termuda 31 tahun dan tertua 79 tahun. Rata-rata umur pasien pada penelitian ini sedikit lebih tua dibandingkan hasil penelitian Trevisol, Moreira, Kerkhoff, Fuchs, dan Fuchs (2011) dengan rata-rata 49,85. Usia lanjut meningkatkan kecenderungan terpaparnya faktor risiko penyakit hipertensi (Wamala, Karyabakabo, Ndungutse, \& Guwatudde, 2009). Umur merupakan faktor resiko yang kuat yang tidak bisa dimodifikasi.
Arteri akan kehilangan fleksibilitasnya seiring dengan proses menua. Umumnya tekanan darah meningkat saat berumur pra lansia tetapi juga dapat terjadi pada sekitar umur 35 tahun atau di atasnya. Ini terjadi karena adanya perubahan pada jantung, perubahan darah, serta hormon.

Kelompok jenis kelamin perempuan lebih dominan dibandingkan laki-laki pada penelitian ini. Sejalan dengan beberapa penelitian sebelumnya (Arif, Rusnoto, \& Hartinah, 2013; Giena et al., 2018; Suoth et al., 2014; Wamala et al., 2009). Namun, studi di Zambia oleh Goma et al. (2011) menemukan bahwa mayoritas responden penelitiannya berjenis kelamin laki-laki. Pada wanita, terdapat hormon estrogen yang melindungi terjadinya hipertensi dan aterosklerosis (kondisi mengeras dan menebalnya pembuluh darah). Laki-laki dianggap lebih rentan mengalami hipertensi karena lebih buruk gaya hidupnya dan level stres yang lebih tinggi. Pria di bawah 55 tahun berkemungkinan lebih besar mengidap hipertensi dibandingkan perempuan. Tetapi setelah usia 55 tahun, wanita lebih cenderung menderita penyakit ini seiring dengan memudarnya kadar estrogen (Evadewi \& Suarya, 2013).

Tingkat pendidikan terdominan pada responden penelitian ini yaitu SD. Penelitian ini sejalan dengan hasil Anggara dan Prayitno (2013) yang menyatakan bahwa responden hipertensi terbanyak dengan level pendidikan yang rendah. Pasien berpendidikan tinggi cenderung dapat mengidentifikasi perilaku kesehatan mereka, memiliki kemauan untuk mencari informasi tentang kondisi kesehatan, dan mudah memahami informasi mengenai hipertensi (Giena et al., 2018).

Jenis pekerjaan responden yang terbesar dalam penelitian ini yaitu petani. Berbeda dengan Kartikasari, Chasani, dan Ismail (2012) yang menyatakan sebagian besar pekerjaan responden hipertensi dalam penelitiannya yaitu ibu rumah tangga. Faktor atau jenis pekerjaan berpengaruh dalam pola aktivitas fisik seseorang, di mana jika pekerjaan tersebut tidak mengandalkan aktivitas fisik yang teratur dapat berpengaruh pada tekanan darah. Individu yang bekerja dengan aktivitas fisik teratur dan benar dapat terhindar atapun kecil resikonya untuk terkena hipertensi (Ningsih \& Rosida, 2017).

Rata-rata IMT responden penelitian ini yaitu 23,37 $\mathrm{kg} / \mathrm{m}^{2}$, dengan rentang $18-28 \mathrm{~kg} / \mathrm{m}^{2}$. Senada dengan temuan penelitian Apriany dan Mulyati (2012) yang mayoritas memiliki IMT di atas $23 \mathrm{~kg} / \mathrm{m}^{2}$. IMT adalah prediktor terkuat terjadinya penyakit hipertensi (Forman, Stampfer, \& Curhan, 2009). IMT berlebihan yang dikategorikan sebagai kegemukan, dapat menyebabkan curah jantung serta 
sirkukasi volume darah meningkat, pencetus berkurangnya resistensi perifier, meningkatkan aktivitas saraf simpatik, aktivitas renin plasma rendah, sehingga memperbesar faktor terkena hipertensi. Selain karena diet, menjaga berat badan proporsional juga dianjurkan karena dapat mengoptimalkan tekanan darah dan mengurangi risiko penyakit kardiovaskular lainnya (Shimbo, 2016).

Responden dalam penelitian ini didominasi kelompok yang tidak merokok. Berlawanan dengan responden penelitian Setyanda, Sulastri, dan Lestari (2015) yang mayoritas aktif merokok. Merokok merupakan faktor lain yang dapat menyebabkan hipertensi. Kandungan zat-zat berbahaya seperti nikotin, dapat memacu kerja jantung lebih keras sehingga tekanan darah meninggi.

Penelitian yang dilakukan Muliyati, Syam, dan Sirajuddin (2011) mendapati bahwa mayoritas responden tidak rutin berolahraga. Hal ini identik dengan temuan pada responden dalam penelitian ini. Aktivitas fisik seperti berolahraga mempunyai manfaat yang sangat bagus untuk mengurangi dan menormalkan tekanan darah. Olahraga dapat memicu pertumbuhan pembuluh darah kapiler baru, sehingga mengurangi hal-hal penghambat pembuluh darah sehinnga tekanan darah dapat terkontrol dengan baik.

Dalam penelitian ini didapati bahwa lebih dominan responden yang mempunyai riwayat keturunan hipertensi dari orang tua. Sejalan dengan hasil studi dengan populasi di Indonesia oleh Dedullah, Malonda, dan Joseph (2015). Penelitian lain oleh Ranasinghe, Cooray, Jayawardena, dan Katulanda (2015) pada populasi dewasa di Sri Lanka juga mendapati prevalensi hipertensi secara signifikan lebih tinggi pada kelompok yang memiliki riwayat keluarga hipertensi. Faktor keturunan mempunyai peran yang sangat besar dalam timbulnya penyakit hipertensi (Suiraoka \& Supariasa, 2012), walaupun di sisi lain Agarwal, Williams, dan Fisher (2005) menyebutkan bahwa hubungan antara riwayat orangtua dengan hipertensi dan perkembangan hipertensi pada anak tidak hanya mewakili efek faktor genetik tetapi juga nongenetik.

Terdapat hampir setengah responden yang masuk pada kategori hipertensi derajat 1 . Berbeda dengan penelitian Tyashapsari dan Zulkarnain (2012) yang menyebutkan bahwa mayoritas respondenya masuk ke hipertensi derajat 2. Terkait masalah durasi diagnosis, rata-rata lamanya responden mengidap penyakit hipertensi dalam penelitian ini yaitu selama 2,31 tahun. Angka ini relatif lebih rendah dari hasil penelitian Pandean dan Surachmanto (2016) yaitu 7,07 tahun.
Mayoritas responden penelitian patuh menjaga asupan garamnya sesuai instruksi dari dokter ataupun tenaga kesehatan. Konsisten dengan penelitian Putri (2018) dan Cakir dan Pinar (2006) yang respondennya menerapkan diet rendah garam. Natrium berfungsi sebagai ion utama dalam cairan ekstra seluler, menjaga keseimbangan cairan, natrium juga berperan dalam absorbsi glukosa dan sebagai alat untuk mengangkat zat-zat gizi lain melalui membran, terutama melalui usus sebagai pompa natrium. Namun, asupan berlebihan dapat menyebabkan gangguan keseimbangan tubuh yang akan meningkatkan cairan di dalam tubuh, sehingga tekanan darah menjadi naik.

Responden dalam penelitian ini cenderung hanya mengonsumsi satu jenis obat. Jenis obat CCB adalah yang terbanyak dipakai, sedangkan yang paling sedikit yaitu ACEi. Berbeda halnya pada penelitian Fitrianto, Azmi, dan Kadri (2014) bahwa obat yang sering digunakan oleh pasien hipertensi yaitu golongan diuretik. Banyak penyebab variasi penggunaan obat antihipertensi ini, seperti level keparahan, kondisi pasien seperti komplikasi penyakit, efek samping, serta ketersediaan obat, dan lain-lain.

Kelelahan dialami oleh seluruh responden penelitian ini. Lin et al. (2015) dalam penelitiannya menyebutkan bahwa prevalensi kelelahan dialami lebih dari $1 / 3$ populasi berusia 45 tahun ke atas. Variasi angka prevalensi menurut usia terdapat dalam penelitian Moreh et al. (2010) yang menyebutkan bahwa kelelahan merupakan keluhan yang paling sering dilaporkan di sepanjang periode penelitian oleh $29 \%, 53 \%$, dan $68 \%$ dari responden berusia 70, 78, dan 85 tahun, masing-masingnya. Prevalensi kelelahan juga meningkat pada populasi perempuan (Junghaenel, Christodoulou, Lai, \& Stone, 2011; Rusu, Gee, Lagacé, \& Parlor, 2015). Populasi lansia lebih cenderung mengalami kelelahan dibandingkan remaja. Pada remaja ditemukan hanya berkisar antara 3,0\% dan 18,4\% (Kronholm et al., 2015; Lamers, Hickie, \& Merikangas, 2013).

Harbison, Walsh, dan Kenny (2008) menyebutkan bahwa pasien hipertensi yang mengonsumsi obat lebih menderita kelelahan dibandingkan yang tidak menggunakan obat. Tetapi keparahan kelelahan tidak berkorelasi dengan jumlah obat yang diminum. Pada pasien lansia hipertensi, refleksologi kaki adalah salah satu pilihan intervensi yang dapat menurunkan tekanan darah sistolik, diastolik, juga untuk mengurangi kelelahan (Cho \& Park, 2004).

Gaya hidup secara keseluruhan responden penelitian ini berada dalam rentang sedang. Konsisten dengan 
penelitian Giena et al. (2018) yang hampir 3/4 respondennya memiliki kebiasaan gaya hidup berlevel moderat. Faktor risiko utama hipertensi termasuk ras, obesitas, diabetes, usia, jenis kelamin, alkoholisme, gaya hidup menetap, diet (termasuk asupan garam), dan riwayat keluarga hipertensi. Beberapa faktor ini dapat dimodifikasi melalui intervensi gaya hidup (Goma et al., 2011; Tabrizi, Sadeghi-Bazargani, Farahbakhsh, Nikniaz, \& Nikniaz, 2016). Deteksi terhadap hipertensi tak terkontrol, kepatuhan mengonsumsi obat, dan praktek gaya hidup sehat harus dilakukan oleh tenaga kesehatan, khususnya perawat (Hacihasanoğlu \& Gözüm, 2011).

Shayesteh, Mirzaei, Sayehmiri, Qorbani, dan Mansourian (2016) menyebutkan bahwa terdapat korelasi antara gaya hidup dan hipertensi. Mengingat pentingnya gaya hidup dan dampaknya yang signifikan pada pencegahan penyakit dan pemeliharaan kesehatan, penggunaan program pendidikan tentang nutrisi, aktivitas fisik, dan manajemen stres diperlukan untuk meningkatkan pengetahuan pasien dan mengubah perilaku mereka. Shafieyan et al. (2015) menyatakan intervensi ini harus dimulai sejak dini karena perilaku buruk dimulai dari masa kanak-kanak.

Aktifitas fisik merupakan subskala dengan skor ratarata terendah dalam penelitian ini. Sejalan dengan hasil penelitian Cakir dan Pinar (2006) yang menyebutkan bahwa subskala aktivitas fisik bersama nutrisi dan pengelolaan stres adalah yang terendah saat pengukuran data awal pada kedua kelompok intervensi dan kontrol pasien hipertensi. de Souza Serafim, dos Santos Jesus, dan Pierin (2010) juga menyebutkan lebih dari setengah responden pasien hipertensi tidak melakukan latihan fisik teratur.

Aktivitas fisik rutin adalah salah satu gaya hidup yang telah lama diakui berkaitan dengan pencegahan hipertensi dan beberapa penyakit lain. Rekomendasi aktivitas fisik untuk tekanan darah yaitu latihan dengan intensitas sedang hingga tinggi selama 30 menit dalam beberapa hari, dengan target yang direkomendasikan total 150 menit per minggu. Jika sesuai secara klinis dan tanpa adanya kontraindikasi, aktivitas fisik dan olahraga untuk pengelolaan penyakit dapat berkontribusi signifikan (Lackland \& Voeks, 2014).

Dalam penelitian ini ditemukan ada hubungan yang signifikan antara 2 subskala kelelahan (keparahan dan derajat terganggunya aktivitas sehari-hari) dengan aktivitas fisik. Moreh et al. (2010) menyebutkan bahwa pada lansia kelelahan dapat menyebabkan penurunan aktivitas fisik, selain juga berhubungan dengan peningkatan mortalitas, penurusan status fungsional, dan depresi. Penurunan level aktivitas fisik pada lansia ini terjadi setelah dilakukan pemantauan hampir 5 tahun. Pada populasi orang muda, kelelahan juga ditemukan berhubungan dengan sejumlah faktor risiko yang dapat dimodifikasi, termasuk kurangnya aktivitas fisik, diet buruk, dan obesitas. Tartavoulle et al. (2018) menyatakan pencapaian target pemulihan kondisi kelelahan dapat terjadi karena bantuan aktivitas fisik yang rutin dan aman.

Domain tekanan dan kelelahan secara keseluruhan yang direpresentasi oleh Indeks Kelelahan Global (GFI) berhubungan secara signifikan dengan subskala nutrisi pada gaya hidup responden. Beberapa penelitian mendapati bahwa kegemukan dan pola makan yang buruk ada hubungannya dengan kelelahan (Moreh et al., 2010; Tartavoulle et al., 2018). Deteksi dini kelelahan diduga dapat membantu menemukan intervensi yang tepat untuk mengatasi penyebab dan potensi akibat kelelahan itu sendiri, termasuk memberikan dukungan nutrisi yang baik (Moreh et al., 2010).

Nutrisi adekuat adalah cara sehat yang dapat membantu mengurangi kelelahan (Tartavoulle et al., 2018). Sejalan dengan itu, Baguley, Bolam, Wright, dan Skinner (2017) mengungkapkan bahwa mengonsumsi makanan yang selaras dengan pedoman makan sehat, bersama berolahraga dengan intensitas sedang dapat mengurangi kelelahan pada pria dengan kanker prostat. Haskell et al. (2010) menyebutkan secara spesifik bahwa mengonsumsi vitamin dan mineral menunjukkan penurunan efek negatif kelelahan. Individu sehat dari populasi umum dapat memperoleh manfaat dari tambahan vitamin dan mineral melalui suplemen makanan langsung. Pengaplikasian hal ini pada penderita penyakit kronis seperti hipertensi, tentu saja memerlukan penyesuaian dengan keadaan dan toleransi tubuhnya, terutama bila berhubungan langsung dengan respons kardiovaskuler.

Selain nutrisi, domain tekanan kelelahan juga ditemukan memiliki hubungan yang bermakna dengan hubungan interpersonal. Subskala ini mencakup hubungan dengan pasangan (status pernikahan), keluarga, dan teman. Beberapa penelitian melaporkan bahwa status pernikahan memiliki hubungan dengan kelelahan (Junghaenel et al., 2011; Martin, Chalder, Rief, \& Braehler, 2007). Di Jepang, laki-laki yang belum menikah lebih berpotensi mengalami masalah pada beberapa aspek kelelahan seperti penurunan vitalitas, gangguan fisik, penurunan kemauan untuk bekerja, cemas, dan perasaan depresi). Diduga pernikahan mungkin mempengaruhi kelelahan secara berbeda tergantung kondisi pekerjaannya (Dochi et al., 2007). Berbagi tugas dan tanggung jawab dalam tugas rumah tangga dapat mengurangi perasaan lelah dan kelelahan 
mental dan fisik. Pernikahan juga dapat membantu mengurangi keluhan terhadap kesehatan dan gejala somatik.

Terdapat beberapa keterbatasan dalam penelitian ini. Pendekatan potong lintang dalam penelitian membatasi pengujian hubungan sebab akibat antarvariabel. Pengumpulan data juga hanya dilakukan pada instalasi rawat jalan, khususnya di poli penyakit dalam, dengan mayoritas responden yang direkrut dari klasifikasi hipertensi derajat 1 . Sehingga perlu kehati-hatian dalam mengaplikasikan hasil ini bagi responden yang masuk dalam level hipertensi yang lebih tinggi. Jumlah responden penelitian ini juga relatif kecil dan dalang ruang lingkup yang kecil dibandingkan dengan penelitian berdesain sejenis. Walaupun istilah fatigue cukup rutin digunakan dalam dunia medis, namun penggunaan istilah kelelahan dalam Bahasa Indonesia mempunyai perbedaan makna dengan istilah aslinya dan dapat menimbulkan kesalahan pemahaman pada responden. Kelelahan dalam penelitian ini hanya secara subyektif saja, tanpa pengambilan data menggunakan alat-alat ataupun instrumen yang objektif guna memperkuat hasil penelitian. Begitu juga dengan gaya hidup, karena variabel ini memiliki ruang lingkup yang cukup luas.

\section{Kesimpulan}

Kelelahan multidimensi umum terjadi pada pasien hipertensi. Gaya hidup pasien hipertensi dalam penelitian ini cukup baik, di mana hubungan interpersonal adalah subskala tertinggi. Penderita hipertensi dengan kelelahan yang lebih berat, menerapkan gaya hidup yang lebih baik. Strategi yang lebih efektif dalam penyuluhan kesehatan, konsultasi profesional, support dan sharing group perlu dilakukan untuk memodifikasi gaya hidup pasien hipertensi menjadi lebih baik.

\section{Daftar Pustaka}

Agarwal, A., Williams, G. H., \& Fisher, N. D. (2005). Genetics of human hypertension. Trends in Endocrinology \& Metabolism, $16(3)$, 127-133. doi:10.1016/j.tem.2005.02.009

American Heart Association. (2017). Understanding blood pressure readings. Retrieved from https://www.heart.org/en/healthtopics/high-blood-pressure/understandingblood-pressure-readings

Anggara, F. H. D., \& Prayitno, N. (2013). Faktorfaktor yang berhubungan dengan tekanan darah di Puskesmas Telaga Murni, Cikarang Barat tahun 2012. Jurnal Ilmiah Kesehatan, 5(1), 20-25.
Apriany, R. E. A., \& Mulyati, T. (2012). Asupan protein, lemak jenuh, natrium, serat dan IMT terkait dengan tekanan darah pasien hipertensi di RSUD Tugurejo Semarang. Universitas Diponegoro, Semarang, Jawa Tengah.

Arif, D., Rusnoto, R., \& Hartinah, D. (2013). Faktor-faktor yang berhubungan dengan kejadian hipertensi pada lansia di Pusling Desa Klumpit UPT Puskesmas Gribig Kabupaten Kudus. Jurnal Ilmu Keperawatan dan Kebidanan, 4(2).

Baguley, B. J., Bolam, K. A., Wright, O. R., \& Skinner, T. L. (2017). The effect of nutrition therapy and exercise on cancerrelated fatigue and quality of life in men with prostate cancer: A systematic review. Nutrients, $\quad$ 9(9), 1003-1032. doi:10.3390/nu9091003

Cakir, H., \& Pinar, R. (2006). Randomized controlled trial on lifestyle modification in hypertensive patients. Western Journal of Nursing Research, 28(2), 190-209. doi:10.1177/0193945905283367

Cho, G.-Y., \& Park, H.-S. (2004). Effects of 6-week foot reflexology on the blood pressure and fatigue in elderly patients with hypertension. Journal of Korean Academy of Fundamentals of Nursing, 11(2), 138130.

da Silva, S. S., Colosimo, F. C., \& Pierin, A. M. (2010). The effect of educational interventions on nursing team knowledge about arterial hypertension. Revista da Escola de Enfermagem da USP, 44(2), 488496. doi:10.1590/S008062342010000200035

Damayanti, M. R., Dino, M. J. S., \& Donnelly, F. (2020). A quantitative and qualitative analysis of nurses' lifestyles and community health practices in Denpasar, Bali, Indonesia. Enfermería Clínica, 30(Supplement $\quad 1$ ), 82-89. doi:10.1016/j.enfcli.2019.09.028

de Souza Serafim, T., dos Santos Jesus, E., \& Pierin, A. M. G. (2010). Influence of knowledge on healthy lifestyle in the control of hypertensive. Acta Paulista de Enfermagem, 23(5), 658-664.

Dedullah, R. F., Malonda, N., \& Joseph, W. B. S. (2015). Hubungan antara faktor risiko hipertensi dengan kejadian hipertensi pada masyarakat di Kelurahan Motoboi Kecil Kecamatan Kotamobagu Selatan Kota Kotamobagu. Jurnal Kesehatan Masyarakat, 1(3), 155-163.

DeJean, D., Giacomini, M., Vanstone, M., \& Brundisini, F. (2013). Patient experiences of depression and anxiety with chronic 
disease: A systematic review and qualitative meta-synthesis. Ontario Health Technology Assessment Series, 13(16), 133

Dinas Kesehatan Kabupaten Poso. (2018). Profil Dinas Kesehatan Kabupaten Poso 2018. Poso, Sulawesi Tengah.

Dochi, M., Suwazono, Y., Oishi, M., Sakata, K., Kobayashi, E., \& Nogawa, K. (2007). The relation between cumulative fatigue and marital status in Japanese workers. Behavioral Medicine, 33(2), 55-65. doi:10.3200/BMED.33.2.55-66

Dong, Y., \& Peng, C.-Y. J. (2013). Principled missing data methods for researchers. SpringerPlus, 2(1), 222-238 doi:10.1186/2193-1801-2-222

Enders, C. K., \& Bandalos, D. L. (2001). The relative performance of full information maximum likelihood estimation for missing data in structural equation models. Structural Equation Modeling, 8(3), 430457. doi:10.1207/S15328007SEM0803_5

Evadewi, P. K. R., \& Suarya, L. M. K. S. (2013). Kepatuhan mengonsumsi obat pasien hipertensi di Denpasar ditinjau dari kepribadian tipe A dan tipe B. Jurnal Psikologi Udayana, 1(1), 32-42. doi:10.24843/JPU.2013.v01.i01.p04

Fitrianto, H., Azmi, S., \& Kadri, H. (2014). Penggunaan obat antihipertensi pada pasien hipertensi esensial di poliklinik Ginjal Hipertensi RSUP Dr. M. Djamil tahun 2011. Jurnal Kesehatan Andalas, 3(1), 4548. doi:10.25077/jka.v3i1.24

Forman, J. P., Stampfer, M. J., \& Curhan, G. C. (2009). Diet and lifestyle risk factors associated with incident hypertension in women. JAMA, 302(4), 401-411. doi:10.1001/jama.2009.1060

Giena, V. P., Thongpat, S., \& Nitirat, P. (2018). Predictors of health-promoting behaviour among older adults with hypertension in Indonesia. International Journal of Nursing Sciences, 5(2), 201-205. doi:10.1016/j.ijnss.2018.04.002

Goma, F. M., Nzala, S. H., Babaniyi, O., Songolo, P., Zyaambo, C., Rudatsikira, E., . . Muula, A. S. (2011). Prevalence of hypertension and its correlates in Lusaka urban district of Zambia: A population based survey. International Archives of Medicine, 4(1), 34-39. doi:10.1186/17557682-4-34

Goodpaster, B. H., Park, S. W., Harris, T. B., Kritchevsky, S. B., Nevitt, M., Schwartz, A. V., . . Newman, A. B. (2006). The loss of skeletal muscle strength, mass, and quality in older adults: The health, aging and body composition study. The Journals of Gerontology Series A: Biological Sciences and Medical Sciences, 61(10), 1059-1064. doi:10.1093/gerona/61.10.1059

Green, S. B. (1991). How many subjects does it take to do a regression analysis. Multivariate Behavioral Research, 26(3), 499-510. doi:10.1093/gerona/61.10.1059

Hacihasanoğlu, R., \& Gözüm, S. (2011). The effect of patient education and home monitoring on medication compliance, hypertension management, healthy lifestyle behaviours and BMI in a primary health care setting. Journal of Clinical Nursing, 20(5-6), 692705. doi:10.1111/j.1365-2702.2010.03534.x

Harbison, J. A., Walsh, S., \& Kenny, R. A. (2008). Hypertension and daytime hypotension found on ambulatory blood pressure is associated with fatigue following stroke and TIA. QJM: An International Journal of Medicine, 102(2), 109-115. doi:10.1093/qjmed/hcn146

Haskell, C. F., Robertson, B., Jones, E., Forster, J., Jones, R., Wilde, A., . . . Kennedy, D. O. (2010). Effects of a multi-vitamin/mineral supplement on cognitive function and fatigue during extended multi-tasking. Human Psychopharmacology: Clinical and Experimental, 25(6), 448-461. doi:10.1002/hup.1144

Hozawa, A. (2011). Attributable fractions of risk factors for cardiovascular diseases. Journal of Epidemiology, 21(2), 81-86. doi:10.2188/jea.JE20100081

Iqomatulhaq, H., \& Solehati, T. (2019). Healthy life behavior in pregnant women with risk of preeclampsia in the PHC of Ciparay Bandung District. Journal of Maternity Care and Reproductive Health, 2(1), 23-33. doi:10.36780/jmcrh.v2i1.56

Junghaenel, D. U., Christodoulou, C., Lai, J.-S., \& Stone, A. A. (2011). Demographic correlates of fatigue in the US general population: Results from the patientreported outcomes measurement information system (PROMIS) initiative. Journal of Psychosomatic Research, 71(3), 117-123. doi:10.1016/j.jpsychores.2011.04.007

Karimiyar Jahromy, M., Yousefi Maghsoudbeiki, H., Shamsi, A., Sadeghi, M., \& Charkhandaz, M. (2013). Effect of lifestyle education on the knowledge and performance of patients affected by hypertension. Education \& Ethic in Nursing, 2(4), 7-12.

Kartikasari, A. N., Chasani, S., \& Ismail, A. (2012). Faktor risiko hipertensi pada masyarakat di Desa Kabongan Kidul, Kabupaten 
Rembang. Universitas Diponegoro, Semarang, Jawa Tengah.

Kaufman, N. D., Rajataramya, B., Tanomsingh, S., Ronis, D. L., \& Potempa, K. (2012). Nurse preparedness for the non-communicable disease escalation in Thailand: A crosssectional survey of nurses. Nursing \& Health Sciences, 14(1), 32-37. doi:10.1111/j.1442-2018.2011.00657.x

Kementerian Kesehatan Republik Indonesia. (2019).

Hipertensi si pembunuh senyap. Jakarta: Pusat Data dan Informasi Kementerian Kesehatan Republik Indonesia Retrieved from

https://pusdatin.kemkes.go.id/resources/do wnload/pusdatin/infodatin/infodatinhipertensi-si-pembunuh-senyap.pdf.

Khusniyati, N., Yona, S., \& Kariasa, I. M. (2019). Fatigue, depresi, terhadap kualitas hidup pada pasien hemodialisa. Jurnal Keperawatan Terpadu (Integrated Nursing Journal), $1(2)$,

$1-8$ doi:10.32807/jkt.v1i2.30

Kokubo, Y., Kamide, K., Okamura, T., Watanabe, M., Higashiyama, A., Kawanishi, K., . . . Kawano, Y. (2008). Impact of high-normal blood pressure on the risk of cardiovascular disease in a Japanese urban cohort: The Suita study. Hypertension, 52(4), 652-659. doi:10.1161/HYPERTENSIONAHA.108.1 18273

Kronholm, E., Puusniekka, R., Jokela, J., Villberg, J., Urrila, A. S., Paunio, T., . . . Tynjälä, J. (2015). Trends in self-reported sleep problems, tiredness and related school performance among Finnish adolescents from 1984 to 2011. Journal of Sleep Research, 24(1), 3-10. doi:10.1111/jsr.12258

Lackland, D. T., \& Voeks, J. H. (2014). Metabolic syndrome and hypertension: Regular exercise as part of lifestyle management. Current Hypertension Reports, 16(11), 492 498. doi:10.1007/s11906-014-0492-2

Lainsamputty, F., \& Chen, H.-M. (2018). The correlation between fatigue and sleep quality among patients with heart failure. NurseLine Journal, 3(2), 100-114. doi:10.19184/nlj.v3i2.8580

Lamers, F., Hickie, I., \& Merikangas, K. R. (2013). Prevalence and correlates of prolonged fatigue in a US sample of adolescents. American Journal of Psychiatry, 170(5), 502-510. doi:10.1176/appi.ajp.2012.12040454

Lin, W.-Q., Jing, M.-J., Tang, J., Wang, J.-J., Zhang, H.-S., Yuan, L.-X., \& Wang, P.-X. (2015). Factors associated with fatigue among men aged 45 and older: A cross-sectional study.
International Journal of Environmental Research and Public Health, 12(9), 1089710909. doi:10.3390/ijerph120910897

Martin, A., Chalder, T., Rief, W., \& Braehler, E. (2007). The relationship between chronic fatigue and somatization syndrome: A general population survey. Journal of Psychosomatic Research, 63(2), 147-156. doi:10.1016/j.jpsychores.2007.05.007

Mills, K. T., Bundy, J. D., Kelly, T. N., Reed, J. E., Kearney, P. M., Reynolds, K., . . . He, J. (2016). Global disparities of hypertension prevalence and control: A systematic analysis of population-based studies from 90 countries. Circulation, 134(6), 441-450. doi:10.1161/CIRCULATIONAHA.115.018 912

Moreh, E., Jacobs, J. M., \& Stessman, J. (2010). Fatigue, function, and mortality in older adults. The Journals of Gerontology: Series A, 65(8), 887-895. doi:10.1093/gerona/glq064

Muliyati, H., Syam, A., \& Sirajuddin, S. (2011). Hubungan pola konsumsi natrium dan kalium serta aktifitas fisik dengan kejadian hipertensi pada pasien rawat jalan di RSUP dr. Wahidin Sudirohusodo Makassar. Media Gizi Masyarakat Indonesia, 1(1), 4651.

Ningsih, D. L. R., \& Rosida, L. (2017). Faktorfaktor yang berhubungan dengan kejadian hipertensi pada pekerja sektor informal di Pasar Beringharjo Kota Yogyakarta. Universitas 'Aisyiyah Yogyakarta, Yogyakarta.

Pandean, G. V., \& Surachmanto, E. E. (2016). Hubungan hipertensi dengan fungsi kognitif di Poliklinik SMF Ilmu Penyakit Dalam RSUP Prof. Dr. RD Kandou Manado. $e$ CliniC, 4(1). doi:10.35790/ecl.4.1.2016.12147

Putri, R. (2018). Faktor resiko hipertensi ditinjau dari stres kerja dan kelelahan pada anggota polisi daerah Riau. Psychopolytan: Jurnal Psikologi, 2(1), 36-48.

Rachmawati, Y. D. (2013). Hubungan antara gaya hidup dengan kejadian hipertensi pada usia dewasa muda di Desa Pondok Kecamatan Nguter Kabupaten Sukoharjo. (Undergraduate Thesis), Universitas Muhammadiyah Surakarta, Solo, Jawa Tengah.

Ranasinghe, P., Cooray, D. N., Jayawardena, R., \& Katulanda, P. (2015). The influence of family history of hypertension on disease prevalence and associated metabolic risk factors among Sri Lankan adults. BMC Public Health, 15, 576-576. doi:10.1186/s12889-015-1927-7 
Ridwan, E. S., \& Nurwanti, E. (2016). Gaya hidup dan hipertensi pada lanjut usia di Kecamatan Kasihan Bantul Yogyakarta. Jurnal Ners dan Kebidanan Indonesia, 2(2), 67-70. doi:10.21927/jnki.2014.2(2).67-70

Rusu, C., Gee, M., Lagacé, C., \& Parlor, M. (2015). Chronic fatigue syndrome and fibromyalgia in Canada: prevalence and associations with six health status indicators. Health Promotion and Chronic Disease Prevention in Canada: Research, Policy and Practice, 35(1), 3-11. doi:10.24095/hpcdp.35.1.02

Setyanda, Y. O. G., Sulastri, D., \& Lestari, Y. (2015). Hubungan merokok dengan kejadian hipertensi pada laki-laki usia 3565 tahun di Kota Padang. Jurnal Kesehatan Andalas, $\quad 4(2), \quad 434-440$ doi:10.25077/jka.v4i2.268

Shafieyan, Z., Qorbani, M., Rastegari Mehr, B., Mahboubi, M., Rezapour, A., Safari, O., .. . Mansourian, M. (2015). Association between lifestyle and hypertension in patients referred to health care centers of Ilam City in 2014. Global Journal of Health Science, 8(6), 161-167. doi:10.5539/gjhs.v8n6p161

Shayesteh, H., Mirzaei, A., Sayehmiri, K., Qorbani, M., \& Mansourian, M. (2016). Effect of education intervention on lifestyle of patients with hypertension among the rural population of Lorestan Province. Journal of Lifestyle Medicine, 6(2), 58-63. doi:10.15280/jlm.2016.6.2.58

Shimbo, D. (2016). Dietary and lifestyle factors in hypertension. Journal of Human Hypertension, 30(10), 571-572. doi:10.1038/jhh.2016.57

Suiraoka, I. P., \& Supariasa, I. D. N. (2012). Media pendidikan kesehatan. Yogyakarta: Graha Ilmu.

Suoth, M., Bidjuni, H., \& Malara, R. (2014). Hubungan gaya hidup dengan kejadian hipertensi di Puskesmas Kolongan Kecamatan Kalawat Kabupaten Minahasa Utara. Jurnal Keperawatan, 2(1).

Tabrizi, J. S., Sadeghi-Bazargani, H., Farahbakhsh, M., Nikniaz, L., \& Nikniaz, Z. (2016). Prevalence and associated factors of prehypertension and hypertension in Iranian Population: The Lifestyle Promotion Project (LPP). PLOS ONE, 11(10), e0165264-e0165264.

doi:10.1371/journal.pone.0165264
Tack, B. B. (1991). Dimensions and correlates of fatigue in older adults with rheumatoid arthritis. (Doctor of Philosopy Doctoral Thesis), University of California, San Francisco.

Tartavoulle, T. M., Karpinski, A. C., Aubin, A., Kluger, B. M., Distler, O., \& Saketkoo, L. A. (2018). Multidimensional fatigue in pulmonary hypertension: Prevalence, severity and predictors. ERJ Open Research, 4(1), 00079-02017. doi:10.1183/23120541.00079-2017

Trevisol, D. J., Moreira, L. B., Kerkhoff, A., Fuchs, S. C., \& Fuchs, F. D. (2011). Health-related quality of life and hypertension: A systematic review and meta-analysis of observational studies. Journal of Hypertension, 29(2), 179-188. doi:10.1097/HJH.0b013e328340d76f

Tyashapsari, M. M. W. E., \& Zulkarnain, A. K. (2012). Penggunaan obat pada pasien hipertensi di instalasi rawat inap Rumah Sakit Umum Pusat Dr. Kariadi Semarang. Majalah Farmaseutik, 8(2), 145-151. doi:10.22146/farmaseutik.v8i2.24068

Walker, S. N., \& Hill-Polerecky, D. M. (1996). Psychometric evaluation of the healthpromoting lifestyle profile II. University of Nebraska Medical Center. Omaha, Nebraska.

Wamala, J. F., Karyabakabo, Z., Ndungutse, D., \& Guwatudde, D. (2009). Prevalence factors associated with Hypertension in Rukungiri District, Uganda - A community-based study African Health Sciences 9(3), 153-160.

Wang, L.-Y., Li, Y., Li, N., Ding, Y., Shi, N.-N., \& Han, X.-J. (2010). Study on TCM syndrome distribution of 1508 cases of hypertension patients with clinical epidemiology. China Journal of Traditional Chinese Medicine and Pharmacy, 12, 19601963.

World Health Organization. (2013). A global brief on hypertension: Silent killer, global public health crisis: World Health Day 2013. Retrieved from Geneva: https://apps.who.int/iris/handle/10665/7905 9

Yogisutanti, G., Kusnanto, H., Setyawati, L., \& Otsuka, Y. (2013). Kebiasaan makan pagi, lama tidur dan kelelahan kerja (fatigue) pada dosen. KEMAS: Jurnal Kesehatan Masyarakat, $\quad 9(1), \quad$ 53-57. doi:10.15294/kemas.v9i1.2830 